Article

\title{
Effect of Different Composition on Voltage Attenuation of Li-Rich Cathode Material for Lithium-Ion Batteries
}

\author{
Jun Liu ${ }^{1}$, Qiming Liu ${ }^{1}$, Huali Zhu ${ }^{2} \odot$, Feng Lin ${ }^{1}$, Yan Ji ${ }^{1}$, Bingjing Li $^{1}$, Junfei Duan ${ }^{1}$, \\ Lingjun $\mathrm{Li}^{1}$ and Zhaoyong Chen ${ }^{1, *}$ \\ 1 College of Materials Science and Engineering, Changsha University of Science and Technology, \\ Changsha 410114, China; liujun@stu.csust.edu.cn (J.L.); liuqiming@stu.csust.edu.cn (Q.L.); \\ 18216359528@163.com (F.L.); juefly@stu.csust.edu.cn (Y.J.); krystalbingjingli@163.com (B.L.); \\ junfei_duan@csust.edu.cn (J.D.); lingjun.li@csust.edu.cn (L.L.) \\ 2 College of Physics and Electronic Science, Changsha University of Science and Technology, Changsha 410114, \\ China; juliezhu2005@126.com \\ * Correspondence: chenzhaoyongcioc@126.com
}

Received: 30 November 2019; Accepted: 18 December 2019; Published: 20 December 2019

check for updates

\begin{abstract}
Li-rich layered oxide cathode materials have become one of the most promising cathode materials for high specific energy lithium-ion batteries owning to its high theoretical specific capacity, low cost, high operating voltage and environmental friendliness. Yet they suffer from severe capacity and voltage attenuation during prolong cycling, which blocks their commercial application. To clarify these causes, we synthesize $\mathrm{Li}_{1.5} \mathrm{Mn}_{0.55} \mathrm{Ni}_{0.4} \mathrm{Co}_{0.05} \mathrm{O}_{2.5}$ $\left(\mathrm{Li}_{1.2} \mathrm{Mn}_{0.44} \mathrm{Ni}_{0.32} \mathrm{Co}_{0.04} \mathrm{O}_{2}\right)$ with high-nickel-content cathode material by a solid-sate complexation method, and it manifests a lot slower capacity and voltage attenuation during prolong cycling compared to $\mathrm{Li}_{1.5} \mathrm{Mn}_{0.66} \mathrm{Ni}_{0.17} \mathrm{Co}_{0.17} \mathrm{O}_{2.5}\left(\mathrm{Li}_{1.2} \mathrm{Mn}_{0.54} \mathrm{Ni}_{0.13} \mathrm{Co}_{0.13} \mathrm{O}_{2}\right)$ and $\mathrm{Li}_{1.5} \mathrm{Mn}_{0.65} \mathrm{Ni}_{0.25} \mathrm{Co}_{0.1} \mathrm{O}_{2.5}$ $\left(\mathrm{Li}_{1.2} \mathrm{Mn}_{0.52} \mathrm{Ni}_{0.2} \mathrm{Co}_{0.08} \mathrm{O}_{2}\right)$ cathode materials. The capacity retention at $1 \mathrm{C}$ after 100 cycles reaches to $87.5 \%$ and the voltage attenuation after 100 cycles is only $0.460 \mathrm{~V}$. Combining X-ray diffraction (XRD), scanning electron microscope (SEM), and transmission electron microscopy (TEM), it indicates that increasing the nickel content not only stabilizes the structure but also alleviates the attenuation of capacity and voltage. Therefore, it provides a new idea for designing of Li-rich layered oxide cathode materials that suppress voltage and capacity attenuation.
\end{abstract}

Keywords: Li-rich layered oxide; cathode materials; voltage attenuation; lithium-ion batteries; solid-state complexation method

\section{Introduction}

Advanced lithium-ion batteries (LIBs) technology have promoted the rapid development of mobile electronic devices owning to their low cost, long life, lack of any memory effect and environmental friendliness [1-3]. The development of plug in hybrid electric vehicles (PHEVs) and electric vehicles (EVs) puts higher demands on energy density and cruising range [4-6]. Compared to traditional cathode materials, such as $\mathrm{LiCoO}_{2}[7,8]$, spinel $\mathrm{LiMn}_{2} \mathrm{O}_{4}[9,10]$, polyanionic $\mathrm{LiFePO}_{4}[11,12]$, and layered cathode materials $\mathrm{LiMO}_{2}$ [13-16] ( $\left.\mathrm{M}=\mathrm{Ni}, \mathrm{Co}, \mathrm{Mn}\right)$, Li-rich layered oxide cathode materials, represented by the chemical formula $\mathrm{xLi}_{2} \mathrm{MnO}_{3} \cdot(1-\mathrm{x}) \mathrm{LiMO}_{2}(0<\mathrm{x}<1, \mathrm{M}=\mathrm{Ni}, \mathrm{Co}, \mathrm{Mn})$ have received extensive attention from scientists all over the world because they exhibit a reversible capacity exceeding $250 \mathrm{mAh} \cdot \mathrm{g}^{-1}$ between $2 \mathrm{~V}$ and $4.8 \mathrm{~V}$, as well as their low cost and high energy density $\left(>900 \mathrm{Wh} \cdot \mathrm{Kg}^{-1}\right)[17,18]$. Unfortunately, these cathode materials put up with poor kinetics [19] and severe voltage attenuation [20-22] during prolong cycling, which directly affects their electrochemical 
performance, particularly the energy that the battery can output [23-25]. These disadvantages hinder the commercial development of high specific energy lithium-ion cells with cathodes prepared with the use of lithium-manganese-rich materials.

In order to explore effective ways to alleviate the voltage attenuation of Li-rich cathode materials, scientists have done a lot of research work to identify the origin [6,26-28]. The voltage attenuation can be caused by voltage fade and increase of resistance during cycling [29]. The cause of voltage attenuation is generally attributed to a continuous phase transition from layered phase to spinel during the repeated extraction/insertion processes $[19,21,30]$, corresponding to the irreversible migration of the transition metal (TM) ions, during the course of which they move from the octahedral sites in the TM slab to the octahedral sites in the Li slab during the lithium ion extraction/insertion processes [31]. It is possible for Li-rich layered oxide cathode materials to prevent collapse of the layered structure by minimizing the tension between the neighboring oxygen layers in its deep delithiation state. In addition, another important reason for the voltage attenuation is increase of resistance during cycling [29]. Therefore, the voltage attenuation caused by resistance growth can be reflected in the average voltage as a function of cycling. Researchers believe that surface structure modification and elemental doping can effectively suppress voltage attenuation. For example, there are many reports of interface modifications $\left(\mathrm{Al}_{2} \mathrm{O}_{3}\right.$ [32], $\mathrm{LiFePO}_{4}$ [33], LIPON [32], etc.) will reduce the side reaction between the surface of the positive electrode material and the electrolyte, and enhance the stability of the surface layered structure. elemental doping $\left(\mathrm{Na}^{+}[34], \mathrm{Ce}^{3+} / \mathrm{Ce}^{4+}\right.$, and $\mathrm{Sn}^{4+}[22]$, etc.) may significantly inhibit the Phase transition and stabilize the structure. Furthermore, Burrell et al. explored the effect of cycling temperature on the voltage fade of Li-rich layered oxide cathode materials [35]. Increasing the nickel content can effectively suppress the voltage attenuation in these cobalt-free or high-nickel cathode materials, which is the development trend of lithium-ion batteries in the future $[23,25,36]$. Dahn et al. reported Core-shell (CS) materials allow that the Mn-rich shell can protect the Ni-rich core from electrolyte attack, as well as the Ni-rich core maintains a high and stable average voltage [27,37]. $\mathrm{Li}$ et al. reported that reducing the Co content can significantly suppress voltage attenuation [38]. $\mathrm{Vu}$ et al. reported study the effect of composition on the voltage fade of Li-rich cathode materials with a combinatorial synthesis approach. Although the voltage fade can be reduced by controlling the composition of the system, there is no guarantee that the composition is the layered-layered structure [39]. Therefore, it is very important indication for Li-rich layered oxide cathode material to control the composition of $\mathrm{TM}$ ions in the $\mathrm{LiMO}_{2}$ layer in order to suppress the voltage attenuation.

To further investigate the effect of different compositions in the $\mathrm{LiMO}_{2}$ layer on the physicochemical properties of $\mathrm{Li}$-rich layered oxide cathode materials, we synthesize $\mathrm{Li}_{1.5} \mathrm{Mn}_{0.66} \mathrm{Ni}_{0.17} \mathrm{Co}_{0.17} \mathrm{O}_{2.5}$ $\left(\mathrm{Li}_{1.2} \mathrm{Mn}_{0.54} \mathrm{Ni}_{0.13} \mathrm{Co}_{0.13} \mathrm{O}_{2}\right)$ (LL-111), $\mathrm{Li}_{1.5} \mathrm{Mn}_{0.65} \mathrm{Ni}_{0.25} \mathrm{Co}_{0.1} \mathrm{O}_{2.5}\left(\mathrm{Li}_{1.2} \mathrm{Mn}_{0.52} \mathrm{Ni}_{0.2} \mathrm{Co}_{0.08} \mathrm{O}_{2}\right)$ (LL-523) and $\mathrm{Li}_{1.5} \mathrm{Mn}_{0.55} \mathrm{Ni}_{0.4} \mathrm{Co}_{0.05} \mathrm{O}_{2.5}\left(\mathrm{Li}_{1.2} \mathrm{Mn}_{0.44} \mathrm{Ni}_{0.32} \mathrm{Co}_{0.04} \mathrm{O}_{2}\right)$ (LL-811) cathode materials by means of solid-state complexation method, and the electrochemical properties have been investigated. During these three composition samples, LL-811 exhibits slower voltage decay and more excellent cycle stability during prolong cycling. The capacity retention rate of the LL-811 is $87.5 \%$ at $1 \mathrm{C}$ rate after 100 cycles, and its voltage attenuation is quite low with $0.460 \mathrm{~V}$. The distinctive advantage of this LL-811 Li-rich cathode material may derive from the high nickel content in the layered $(\mathrm{R}-3 \mathrm{~m})$ phase. High-nickel-content Li-rich layered oxide cathode material may cause more $\mathrm{Ni}^{2+}$ ions to occupy the $\mathrm{Li}^{+}$ ion sites in the lithium layer, it can result in a part of nickel to be doped at $\mathrm{Li}^{+}$ion sites [40]. The cation doping, to some extent, can improve the structural stability by supporting the Li slabs and reducing tension of neighboring oxygen layers during the delithiation process [23]. In addition, nickel acts as a stabilizer to reduce the complete transformation of manganese by substitution. The preferential reduction of $\mathrm{Ni}^{4+/ 2+}$ maintains average oxidation state of $\mathrm{Mn}$ above $3+$, as well as suppresses the Jahn-Teller effect caused by $\mathrm{Mn}^{3+}$ ions and effectively improves structural durability [41-43]. 


\section{Materials and Methods}

\subsection{Sample Preparation}

The $\mathrm{Li}_{1.5} \mathrm{Mn}_{0.66} \mathrm{Ni}_{0.17} \mathrm{Co}_{0.17} \mathrm{O}_{2.5}\left(\mathrm{Li}_{1.2} \mathrm{Mn}_{0.54} \mathrm{Ni}_{0.13} \mathrm{Co}_{0.13} \mathrm{O}_{2}\right), \mathrm{Li}_{1.5} \mathrm{Mn}_{0.65} \mathrm{Ni}_{0.25} \mathrm{Co}_{0.1} \mathrm{O}_{2.5}\left(\mathrm{Li}_{1.2} \mathrm{Mn}_{0.52} \mathrm{Ni}_{0.2} \mathrm{Co}_{0.08} \mathrm{O}_{2}\right)$, $\mathrm{Li}_{1.5} \mathrm{Mn}_{0.55} \mathrm{Ni}_{0.4} \mathrm{Co}_{0.05} \mathrm{O}_{2.5}\left(\mathrm{Li}_{1.2} \mathrm{Mn}_{0.44} \mathrm{Ni}_{0.32} \mathrm{Co}_{0.04} \mathrm{O}_{2}\right)$ cathode materials (marked as LL-111, LL-523, LL-811, respectively.) were synthesized by a solid-sate complexation method using citric acid monohydrate as complexing agent with analytical grade chemicals $\mathrm{LiAc} \cdot 2 \mathrm{H}_{2} \mathrm{O}$ (Excess $5 \%, \mathrm{AR}, 99 \%$ ), $\mathrm{Ni}(\mathrm{Ac})_{2} \cdot 4 \mathrm{H}_{2} \mathrm{O}(\mathrm{AR}, 98 \%), \mathrm{Co}(\mathrm{Ac})_{2} \cdot 4 \mathrm{H}_{2} \mathrm{O}(\mathrm{AR}, 99.5 \%), \mathrm{Mn}(\mathrm{Ac})_{2} \cdot 4 \mathrm{H}_{2} \mathrm{O}(\mathrm{AR}, 99 \%)$, citric acid monohydrate (AR, 99.5\%). The molar ratio between transition metal ion and citric acid monohydrate was 1:1. Using a certain amount of absolute ethanol as a solvent, a stoichiometric amount of above reagents were mixed thoroughly and ball milled at the speed of $200 \mathrm{rpm}$ continuously for $4 \mathrm{~h}$. After ball milling, it was dried in an oven at $80^{\circ} \mathrm{C}$ for $24 \mathrm{~h}$ in order to get a uniform mixed precursor. The precursor was ball milled for $30 \mathrm{~min}$ and precalcined at $450{ }^{\circ} \mathrm{C}$ for $6 \mathrm{~h}$ in air to eliminate the organic substances then was calcined at $900{ }^{\circ} \mathrm{C}, 900^{\circ} \mathrm{C}, 800^{\circ} \mathrm{C}$ for $12 \mathrm{~h}$ in air at the rate of $5^{\circ} \mathrm{C} \cdot \mathrm{min}^{-1}$, respectively. And finally, these required samples were obtained.

\subsection{Materials Characterizations}

The crystallographic structure LL-111, LL-523 and LL-811 cathode materials were carried out by X-ray diffraction (XRD, Bruker D8, Karlsruhe, Germany) with Cu K $\alpha$ radiation $(\lambda=1.54056 \AA)$ in the range of $10-90^{\circ}$ with the speed of $5^{\circ} \mathrm{min}^{-1}$. The microscopic morphology was investigated with scanning electron microscopy (SEM, TESCAN MIRA3 LMU, Brno, Czech Republic) and transmission electron microscopy (TEM, TECNAI G2 F20, Hillsboro, America).

Electrochemical performance of the samples was characterized using galvanostatic chargedischarge tests with two-electrode coin cells (type CR-2025, Shenzhen, China). All the charge-discharge processes of our CR-2025 cells except for the first cycle was measured under a voltage window of 2-4.6 V. The synthesized sample, acetylene black (AR, Hersbit Chemical Co., Ltd., Shanghai, China) and polyvinylidene difluoride (PVDF, FR905, San ai fu New Material Technology Co., Ltd., Shanghai, China) with a weight ratio of 8:1:1 to make a slurry in the N-methyl pyrrolidone (NMP) solvent. The slurry was uniformly coated onto aluminum foil as current collector and then dried at $120{ }^{\circ} \mathrm{C}$ for $6 \mathrm{~h}$ under vacuum oven. Cells were assembled in an Argon-filled glove box with $\mathrm{H}_{2} \mathrm{O}_{\text {and } \mathrm{O}_{2}}$ contents below $0.01 \mathrm{ppm}$, using the metallic lithium foil as an anode. The electrolyte was $1 \mathrm{M}$ LiPF6 dissolved in ethyl carbonate (EC) and dimethyl carbonate (DMC) (1:1 in volume) and the separator was Celgard-2500 membrane.

The Galvanostatic charge-discharge measurements were carried out using NEWARE CT-4008 battery testing system (Shenzhen, China) within the voltage range of $2.0-4.8 \mathrm{~V}$ at $25{ }^{\circ} \mathrm{C}$. Cyclic voltammetry (CV) and AC impedance (EIS, $1 \mathrm{MHz}-0.1 \mathrm{MHz}$ ) using a CHI660E electrochemical workstation (Shanghai, China).

\section{Results and Discussion}

\subsection{Crystal Structure and Microstructure}

Using citric acid monohydrate as complexing agent, the cathode materials LL-111, LL-523, and LL-811 were synthesized by a solid-state complexation method. The phase and crystal structure of the above cathode materials were respectively analyzed by XRD. The XRD patterns of the sample LL-111, LL-523, LL-811 are shown in Figure 1. Using the JADE 6.5 analysis software to analyze the XRD data, the diffraction peaks of three samples can be indexed to a typical $\alpha-\mathrm{NaFeO}_{2}$ structure (R-3m) and the enlargements of the small region from 20 to $24^{\circ}$ are attributed to $\mathrm{Li}_{2} \mathrm{MnO}_{3}$ phase $(\mathrm{C} 2 / \mathrm{m})[44,45]$. Complete splitting of the two pair diffraction peaks $(006) /(012)$ and $(018) /(110)$ indicates the integrity of the layered structure for all samples. It is noted that, the intensity of $\mathrm{Li}_{2} \mathrm{MnO}_{3}$ characteristic peak gradually decreases with the metallic nickel content increasing. 

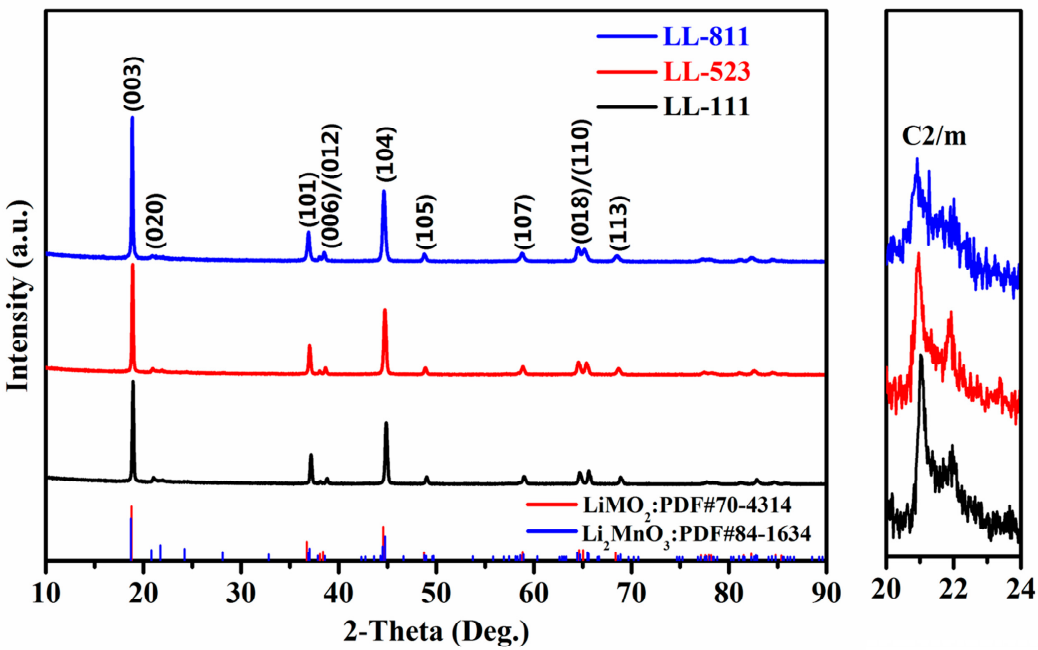

Figure 1. XRD patterns of LL-111, LL-523, LL-811, which adopts a $\alpha-\mathrm{NaFeO}_{2}$ structure. The XRD patterns on the right show the enlargement of $\mathrm{Li}_{2} \mathrm{MnO}_{3}$ characteristic peak over a small $2 \theta$ region.

The surface morphologies of LL-111, LL-523, LL-811 samples and corresponding element compositions are shown in Figure 2. As seen in Figure 2a-c, three samples show irregular polyhedral morphology with a size of approximately $200-500 \mathrm{~nm}$, which is consistent with previous literatures [6,46,47]. In Figure $2 \mathrm{~d}-\mathrm{f}$, the primary particles of three samples show different degrees of agglomeration. As the nickel content increases, particle agglomeration becomes more and more seriously. Besides, the interface between the particles is blurred and even disappears. As seen in Figure $2 \mathrm{~g}-\mathrm{i}$, the actual ratios of LL-111 and LL-523, LL-811 cathode materials are basically in accordance with the designed values. However, LL-811 (Figure 2i) shows a Mn-rich trend on the surface, which may be mainly due to the concentration gradient of $\mathrm{Ni} / \mathrm{Mn}$ with the nickel content increasing.
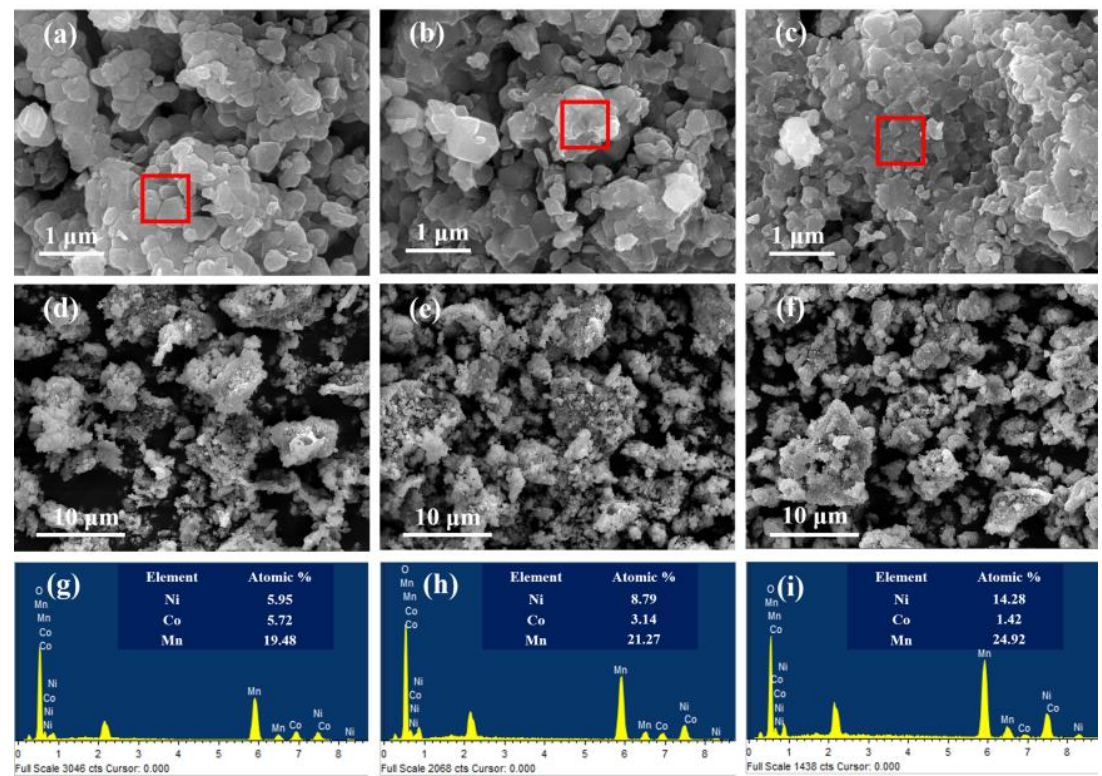

Figure 2. SEM images of LL-111 (a,d), LL-523 (b,e), LL-811 (c,f); Elemental mapping images (g-i) of LL-111, LL-523, LL-811, respectively.

To explore the precise structural properties of Li-rich cathode materials with high nickel content, TEM and HRTEM images are shown in Figure 3. As seen in Figure 3a,d,g the edge of LL-811 cathode material is evenly distributed. Besides, it has relatively straight and continuous lattice fringes, and the interplanar spacing of (003) crystal plane is $4.72 \AA$ (Figure $3 \mathrm{~b}$ ), which shows the characteristics of 
good layered structure material (FFT results in insets of Figure 3c). The lattice fringes of Figure 3e show a distinct two-phase composite (FFT results in insets of Figure 3f). As clearly seen in Figure 3g, the internal phase distribution of the bulk is not very uniform, and Figure $3 \mathrm{~h}$ further verifies this phenomenon. Figure $3 \mathrm{~h}$ and FFT results show three kinds of different plane spaces and crystal plane orientations, which represent the (003) crystal plane of the LL-811 structure $(4.72 \AA)$, the (006) crystal plane of the LL-811 structure $(2.36 \AA)$, two-phase $\left(\mathrm{Li}_{2} \mathrm{MnO}_{3}\right.$ and $\left.\mathrm{LiMO}_{2}\right)$ composite, respectively.
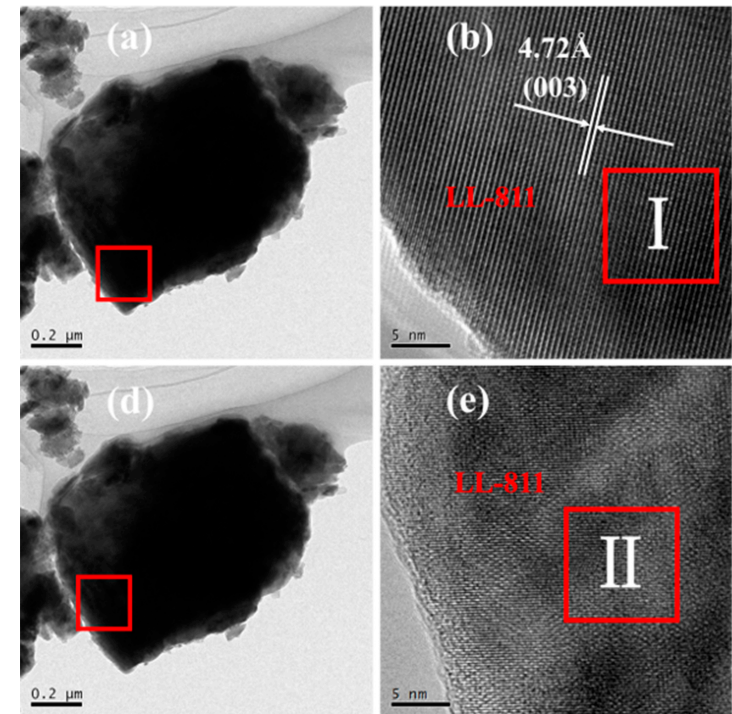

(e)
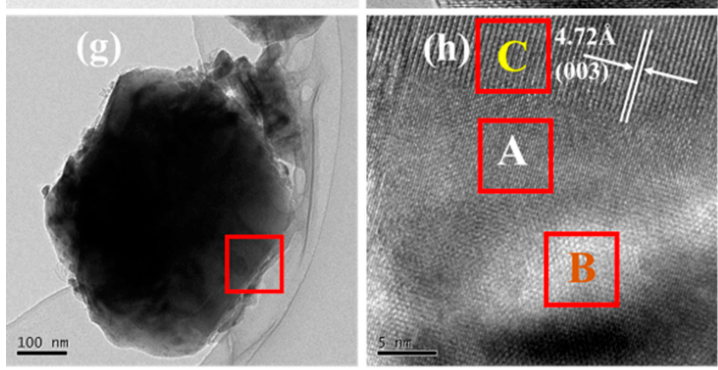
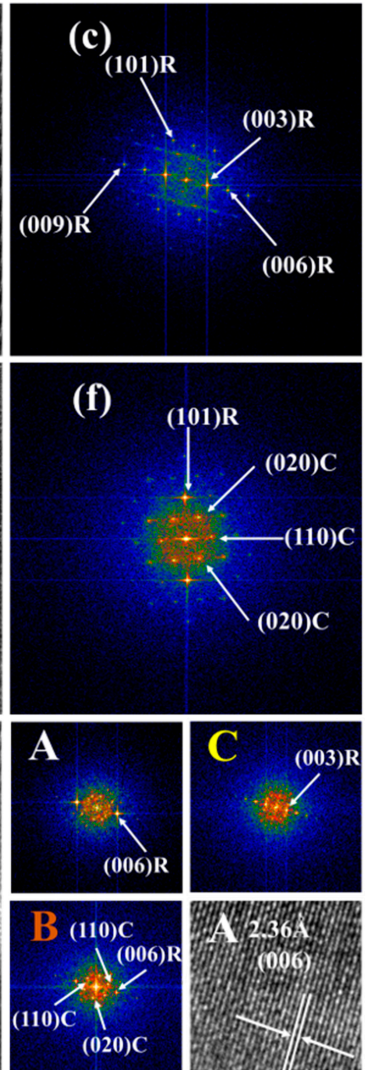

Figure 3. TEM images: (a,d,g), HRTEM images: (b,e,h) of selected regions of LL-811 and corresponding to the Fast Fourier transform (FFT) images of I and II regions: $(\mathbf{c}, \mathbf{f})$.

In order to further verify the elemental uniformity of the LL-811 sample, the EDX linear scanning of the single particle was carried out in Figure $4 \mathrm{a}, \mathrm{b}$. A very important message can be obtained from Figure $4 b$, in which the content of Mn element gradually increases from internal to external and Mn-rich phase appears on the surface. However, the change trend of nickel element is opposite, which may be mainly due to the segregation of $\mathrm{Mn}$ and Ni elements. The segregation may be induced by citric acid and be also due to the bond formation of the layered material itself [48,49]. Nickel has high catalytic activity and is easy to react with electrolyte, while Mn-rich on the surface can effectively inhibit the reaction. The Mn-rich surface phenomenon may explain the excellent prolong cycling stability of LL-811 cathode materials [25,27]. 

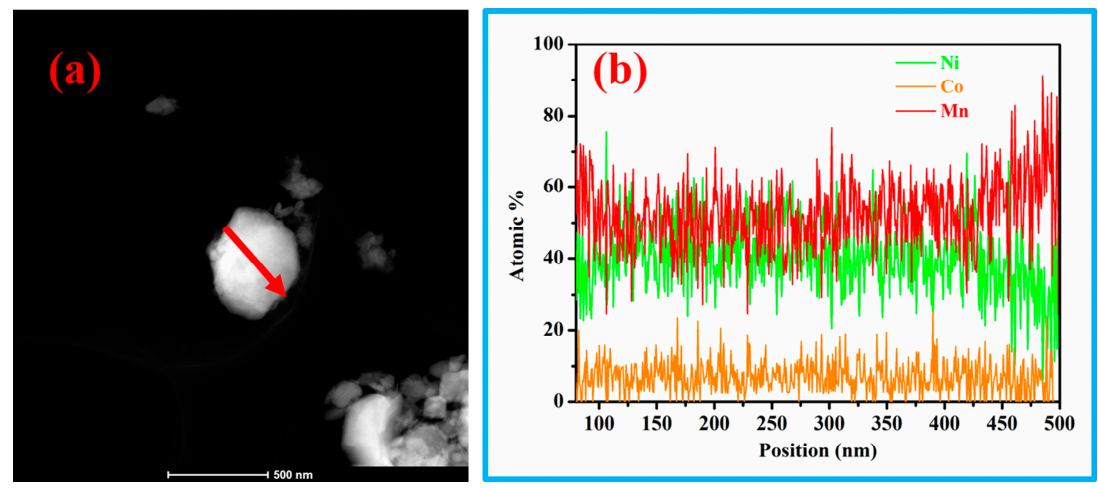

Figure 4. (a) TEM image of LL-811 single particle; (b) corresponding to the Energy dispersive X-ray linear scanning.

\subsection{Electrochemical Charge/Discharge Behavior}

In order to evaluate the electrochemical property of the samples LL-111, LL-523, and LL-811, the first charge-discharge curves, rate performances from $0.1 \mathrm{C}$ to $5 \mathrm{C}$ and cycling performances at $1 \mathrm{C}$ $\left(1 \mathrm{C}=200 \mathrm{mAh} \cdot \mathrm{g}^{-1}\right)$ between $2 \mathrm{~V}$ to $4.8 \mathrm{~V}$ are shown in Figure 5. As shown in Figure 5a, there are two distinct voltage plateaus during the first charge process: (1) a smooth voltage plateau below $4.5 \mathrm{~V}$ and (2) a long voltage plateau about $4.5 \mathrm{~V}$ [50]. The first discharge capacities of LL-111, LL-523, LL-811 are $284.6 \mathrm{mAh} \cdot \mathrm{g}^{-1}, 263.0 \mathrm{mAh} \cdot \mathrm{g}^{-1}, 207.4 \mathrm{mAh} \cdot \mathrm{g}^{-1}$, respectively.

LL-111 samples at $1 \mathrm{C}$ delivers $206.4 \mathrm{mAh} \cdot \mathrm{g}^{-1}$ and about $98.5 \%$ of the capacity is maintained even after 100 cycles. The first discharge capacity of LL-523 at $1 \mathrm{C}$ is $194.1 \mathrm{mAh} \cdot \mathrm{g}^{-1}$ and about $80.0 \%$ of the capacity is maintained after 100 cycles. In contrast to LL-111 and LL-523, the capacity retention of the LL-811 is $87.5 \%$ after 100 cycles, although the first discharge capacity of LL-811 at $1 \mathrm{C}$ only is $154.6 \mathrm{mAh} \cdot \mathrm{g}^{-1}$. By comparison, the cycle stability of the high-nickel-content LL-811 cathode material is more excellent. It can be attributed to that nickel ions easily migrate out of the TM layer to support the structure instead of being trapped in the middle tetrahedral layer [23].

Figure $5 \mathrm{c}$ shows the rate performance of these three samples at different current densities of $0.1 \mathrm{C}$, $0.2 \mathrm{C}, 0.5 \mathrm{C}, 1 \mathrm{C}, 3 \mathrm{C}, 5 \mathrm{C}$ at $25^{\circ} \mathrm{C}$ between $2 \mathrm{~V}$ and $4.8 \mathrm{~V}$. As seen in Figure $5 \mathrm{c}$, the discharge capacities of LL-111, LL-523, and LL-811 are $130.8 \mathrm{mAh} \cdot \mathrm{g}^{-1}, 118.9 \mathrm{mAh} \cdot \mathrm{g}^{-1}$, and $100.5 \mathrm{mAh} \cdot \mathrm{g}^{-1}$, respectively at $5 \mathrm{C}$. The low rate capacity is ascribed to the sluggish kinetics of high nickel Li-rich layered oxide cathode materials discussed in the present paper. The method of calculating the lithium ion diffusion coefficient by EIS measurement is the same as the previous paper [51]. After EIS measurement, $\mathrm{Li}^{+}$ diffusion coefficient of LL-111, LL-523, and LL-811 three samples are $2.77 \times 10^{-14} \mathrm{~cm}^{2} \mathrm{~S}^{-1}, 3.70 \times 10^{-14}$ $\mathrm{cm}^{2} \mathrm{~S}^{-1}$, and $1.32 \times 10^{-14} \mathrm{~cm}^{2} \mathrm{~S}^{-1}$, respectively. Moreover, as seen in Figure $5 \mathrm{~g}$, the charge transfer impedance (Rct) is $212 \Omega, 352 \Omega$, and $606.7 \Omega$ for the LL-111, LL-523, and LL-811 samples. The Rct of high nickel LL-811 cathode material is very large compared to the other two samples, which can be attributed to the low electronic conductivity.

The most striking performance feature of LL-811 cathode materials is its low voltage attenuation after prolong cycling. Figure 5e shows the relationship between the average voltage and cycle number. The voltage attenuation is approximately $0.460 \mathrm{~V}$ after 100 cycles at $1 \mathrm{C}$, while for LL-111 and LL-523, the voltage attenuation is reached up to $0.665 \mathrm{~V}$ and $0.600 \mathrm{~V}$, respectively. 

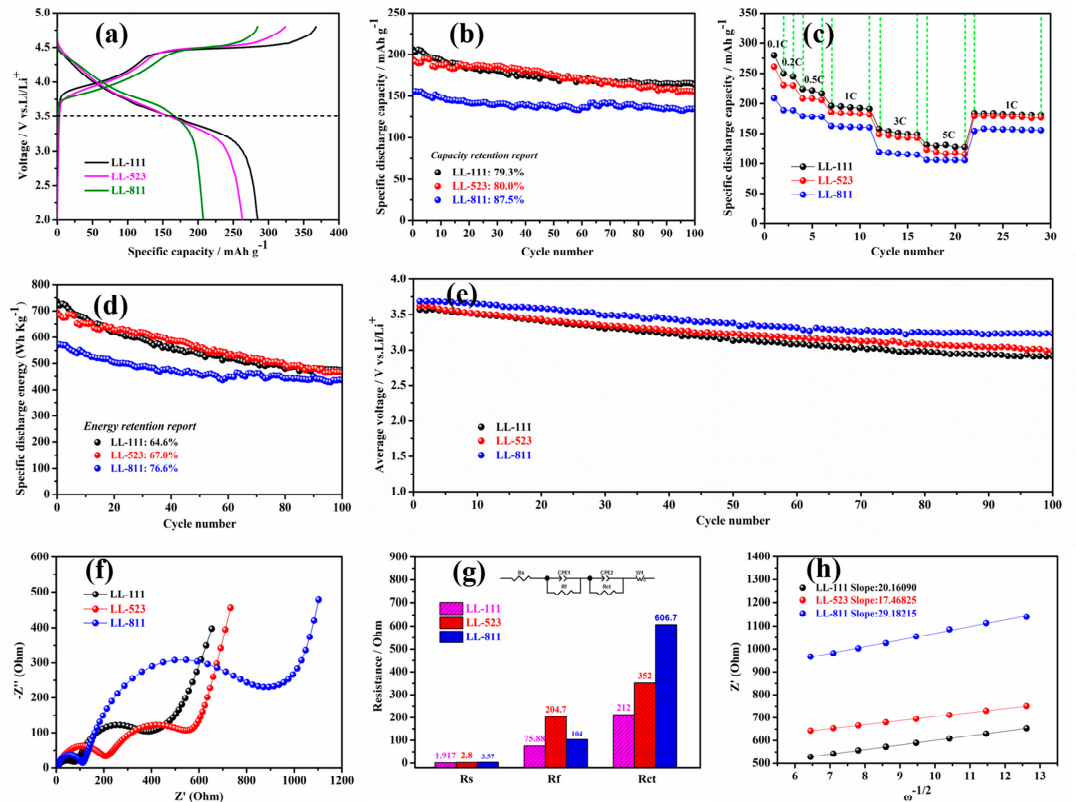

Figure 5. Electrochemical performances: (a) First charge- discharge curves at $0.1 \mathrm{C}$; (b) The cycle performances at $1 \mathrm{C} ;(\mathbf{c})$ The rate performances from $0.1 \mathrm{C}$ to $5 \mathrm{C}$; (d) Specific discharge energy cures at $1 \mathrm{C}$; (e) Average voltage attenuation curves after 100 cycles at $1 \mathrm{C}$; Nyquist plots: (f) Fresh cells; (g) Fitted impedance data of LL-111, LL-523, and LL-811 cells between $2 \mathrm{~V}$ to $4.8 \mathrm{~V}$; (h) The typical plots of $Z^{\prime}$ vs. $\omega^{-1 / 2}$ at low frequency.

To further illustrate the voltage attenuation phenomenon of Li-rich cathode materials upon cycling, discharge curves with different cycles between $2 \mathrm{~V}$ to $4.8 \mathrm{~V}$ at $1 \mathrm{C}$ and cyclic voltammetry (CV) curves of LL-111, LL-523, and LL-811 are shown in Figure 6. As seen in Figure 6a-c, voltage attenuates rapidly at 1 C for LL-111, and for LL-523 it is slower than LL-111, whereas for LL-811 it is the lowest. Figure $6 \mathrm{~d}-\mathrm{f}$ clearly characterize that the three samples display distinct oxidation peaks appeared at $4.0 \mathrm{~V}$ during the first cycle, corresponding to the oxidation reactions of $\mathrm{Ni}^{2+/ 3+/ 4+}$ and $\mathrm{Co}^{3+/ 4+}$; and the oxidation peak at $4.6 \mathrm{~V}$ corresponds to the activation process of $\mathrm{Li}_{2} \mathrm{MnO}_{3}$ [52]. The reduction peaks at 3.3 V, 3.6 V, $4.1 \mathrm{~V}$ reflect $\mathrm{Mn}^{4+/ 3+}, \mathrm{Ni}^{4+/ 3+}, \mathrm{Co}^{4+/ 3+}$ [53], respectively. By comparison, as seen clearly in Figure $6 \mathrm{~d}-\mathrm{f}$, the voltage decay is minimal for LL-811 after 3 cycles, which is consistent with the phenomenon observed with the voltage attenuation curves. LL-111 and LL-523 Li-rich materials suffers from voltage attenuation after prolong cycling, especially LL-111, for which its capacity mainly came from the low voltage region [23]. Therefore, the specific energy (specific energy = specific capacity $\times$ average voltage) output of the battery further lowered upon cycling owing to the disappointing cycle stability and severe voltage attenuation for LL-111 and LL-523 cathode materials. This is due to the phase transformation from layered to spinel-like or rock-salt phases during repeated charge and discharge cycles. As seen in Figure 5d, the absolute value of specific energy of LL-111, LL-523, and LL-811 cathode materials at the 100th cycle is $474.82,465.88,435.68 \mathrm{Wh} \cdot \mathrm{Kg}^{-1}$, respectively. Comparing with LL-111 and LL-523 (64.6\% and 67.0\% energy retention after 100 cycles, respectively), the specific energy retention was $76.7 \%$ for LL- 811 after 100 cycles. The excellent cell properties of LL-811 indicate that increasing the nickel content could significantly inhibit the intrinsic voltage attenuation of Li-rich materials. These consequences demonstrate that high-nickel-content Li-rich cathode materials, such as LL-811, exhibit outstanding structural durability during prolong cycling, which will promote the commercialization of Li-rich cathode materials. 

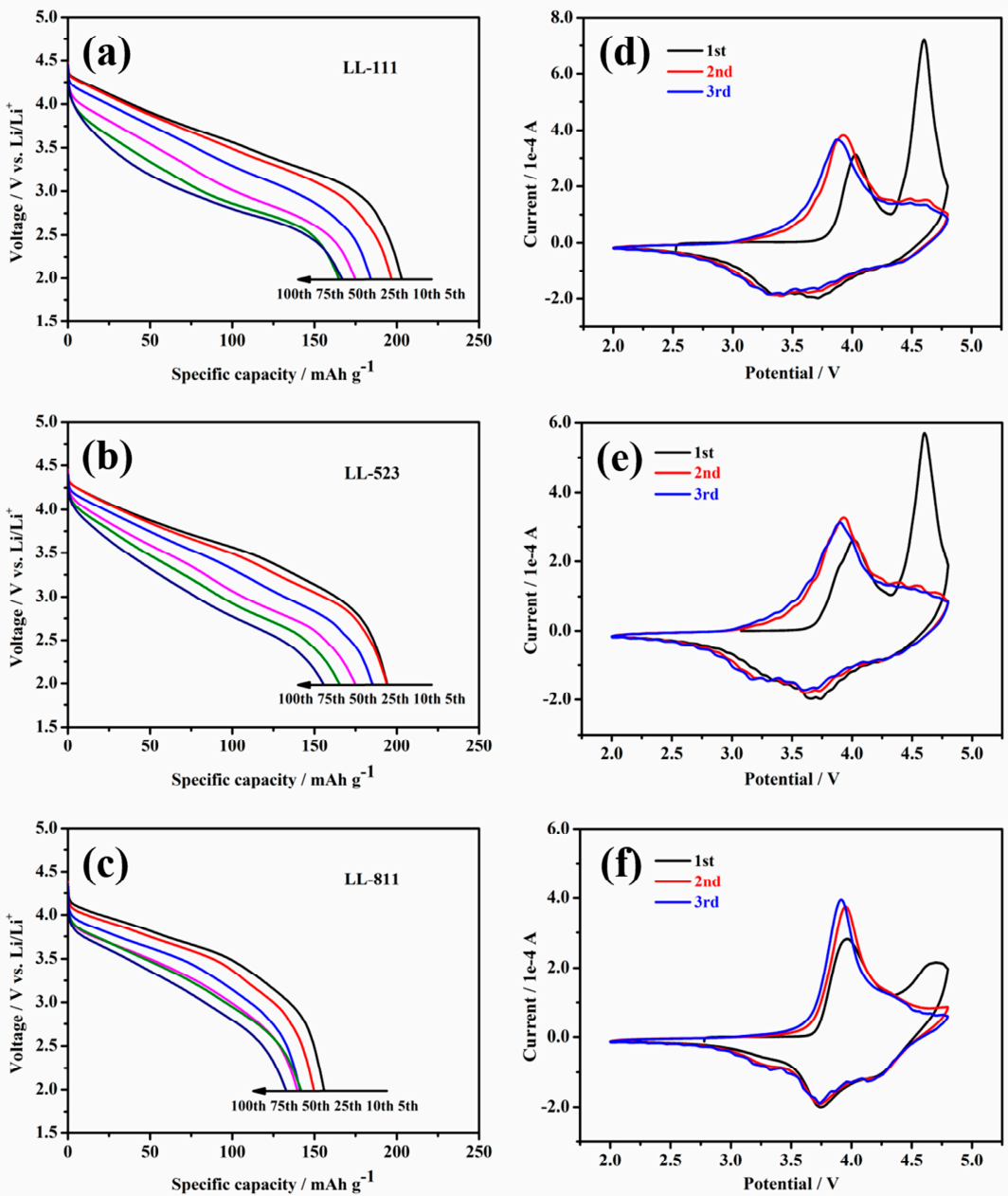

Figure 6. Discharge curves with different cycles between $2 \mathrm{~V}$ to $4.8 \mathrm{~V}$ at $1 \mathrm{C}$ and Cyclic Voltammetry (CV) curves of LL-111 (a,d), LL-523 (b,e), and LL-811 (c,f).

To further assess the effect of nickel content on the structural durability of Li-rich cathode materials, the XRD patterns of LL-111, LL-523, LL-811 before and after 100 cycles are shown in Figure 7. The intensity ratios of both the (003) and (104) peaks of LL-111, LL-523, and LL-811 are shown in Table 1. Compared to LL-111 and LL-523, the intensity ratio of the (003) and (104) peaks of the LL-811 cathode material is still greater than 1.2 after 100 cycles [54,55], which indicates that the high nickel cathode materials can maintain their structural durability and inhibit the phase transformation to a certain degree during prolong cycling.

In this paper, Li-rich layered oxide cathode materials with different compositions are designed and prepared. From the above discussion results, the sensitivity of the voltage attenuation phenomenon to the composition is relatively large. 


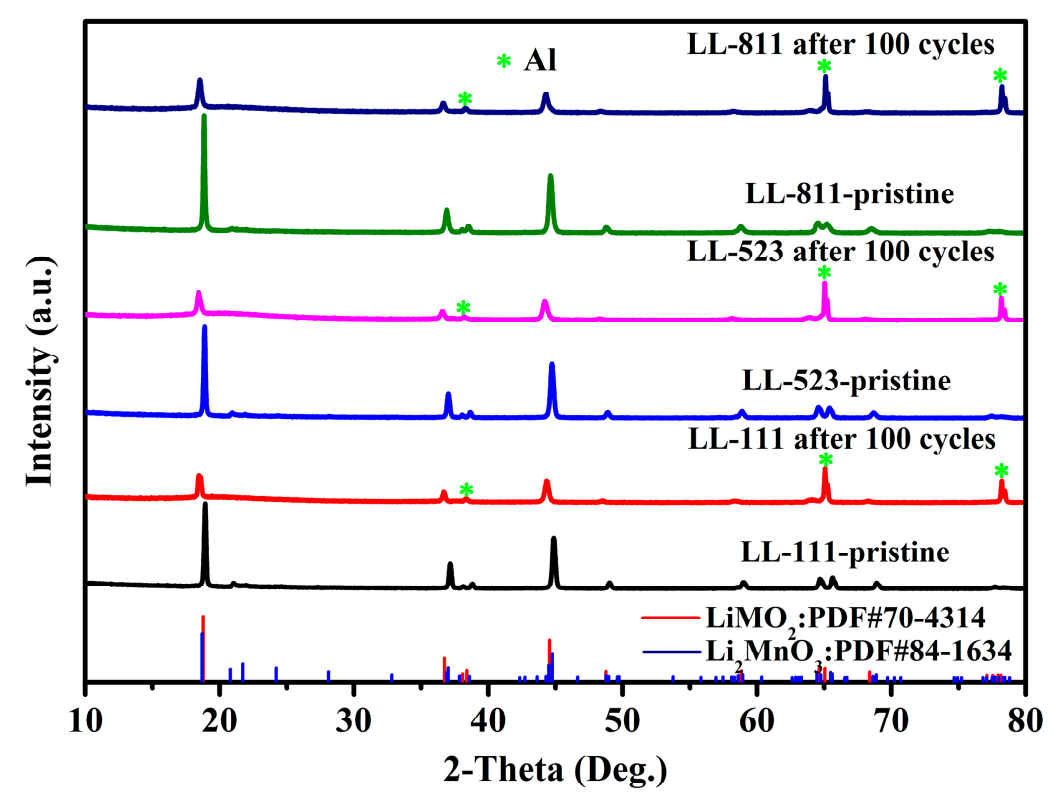

Figure 7. XRD patterns of LL-111, LL-523, LL-811 before and after 100 cycles.

Table 1. The intensity of (003) and (104) and the ratios $\mathrm{I}_{(003)} / \mathrm{I}_{(104)}$ of LL-111, LL-523, and LL-811 initial samples and cycled electrodes by calculating from the XRD data.

\begin{tabular}{ccccccc}
\hline Samples & $\mathbf{I}_{\mathbf{( 0 0 3 )}}$ & $\mathbf{I}_{(\mathbf{1 0 4 )}}$ & ${\text { Initial } \mathbf{I}_{(\mathbf{0 0 3})} / \mathbf{I}_{(\mathbf{1 0 4})}}$ & $\mathbf{I}_{\mathbf{( 0 0 3 )}}$ & $\mathbf{I}_{\mathbf{( 1 0 4 )}}$ & Cycled $\mathbf{I}_{\mathbf{( 0 0 3 )}} / \mathbf{I}_{\mathbf{( 1 0 4 )}}$ \\
\hline LL-111 & 6553 & 3941 & 1.6628 & 2215 & 1803 & 1.2285 \\
LL-523 & 7017 & 4189 & 1.6751 & 2286 & 1611 & 1.4190 \\
LL-811 & 9116 & 4531 & 2.0120 & 2670 & 1563 & 1.7083 \\
\hline
\end{tabular}

\section{Conclusions}

In this paper, LL-111, LL-523, and LL-811 cathode materials were successfully synthesized by a solid-sate complexation method using citric acid monohydrate as complexing agent. Compared to the LL-111 and LL-523, the high-nickel-content LL-811 cathode material shows an excellent cycling stability (capacity retention of $87.5 \%$ at $1 \mathrm{C}$ rate after 100 cycles and energy retention of $76.7 \%$ at $1 \mathrm{C}$ rate after 100 cycles) and suppresses voltage attenuation (only $0.460 \mathrm{~V}$ after 100 cycles) during prolong cycling. CV curves also show that the high-nickel-content LL-811 cathode material exhibits less polarization during cycling. What is more, cycled XRD results demonstrate that increasing the nickel content can effectively maintain structural stability. The results show that the sensitivity of the voltage attenuation to the composition is relatively large. This proves that it is very important for Li-rich layered oxide cathode materials to control the composition of TM ions in the $\mathrm{LiMO}_{2}$ layer. This further demonstrates that the nickel content plays a very important role in stabilizing the structure and suppressing the voltage attenuation. This paper provides a reference for the composition design of Li-rich layered oxide materials with the high nickel content.

Author Contributions: Methodology and Conceptualization, Z.C., J.L., and Q.L.; Resources, Z.C. and H.Z.; Data Curation, Y.J., B.L., J.L., and F.L.; Writing-Original Draft Preparation, J.L.; Writing-Review and Editing, Q.L., L.L., and J.D.; Funding Acquisition, Z.C. and H.Z. All authors have read and agreed to the published version of the manuscript.

Funding: This work was supported by the National Natural Science Foundation of China (No. 51874048), the National Science Foundation for Young Scientists of China (No. 51604042), the Research Foundation of Education Bureau of Hunan Province (No. 19A003) and Scientific Research Fund of Changsha Science and Technology Bureau (No. kq1901100) and Postgraduate Innovative Test Program of Hunan Province.

Conflicts of Interest: The authors declare no conflict of interest. 


\section{References}

1. Li, J.F.; Li, M.; Zhang, L.; Wang, J.Z. General synthesis of $x \operatorname{Li}_{2} \mathrm{MnO}_{3} \cdot(1-x) \mathrm{LiNi}_{1 / 3} \mathrm{Co}_{1 / 3} \mathrm{Mn}_{1 / 3} \mathrm{O}_{2}(\mathrm{x}=1 / 4,1 / 3$, and 1/2) hollow microspheres towards enhancing the performance of rechargeable lithium ion batteries. J. Mater. Chem. A 2016, 4, 12442-12450. [CrossRef]

2. Chen, Z.Y.; Yan, X.Y.; Xu, M.; Cao, K.F.; Zhu, H.L.; Li, L.J.; Duan, J.F. Building Honeycomb-Like Hollow Microsphere Architecture in a Bubble Template Reaction for High-Performance Lithium-Rich Layered Oxide Cathode Materials. ACS Appl. Mater. Interfaces 2017, 9, 30617-30625. [CrossRef]

3. Yang, H.P.; Wu, H.H.; Ge, M.Y.; Li, L.J.; Yuan, Y.F.; Yao, Q.; Chen, J.; Xia, L.F.; Zheng, J.M.; Chen, Z.Y.; et al. Simultaneously Dual Modification of Ni-Rich Layered Oxide Cathode for High-Energy Lithium-Ion Batteries. Adv. Funct. Mater. 2019, 29, 1808825-1808837. [CrossRef]

4. Whittingham, M.S. Lithium Batteries and Cathode Materials. Chem. Rev. 2004, 104, 4271-4302. [CrossRef]

5. Armand, M.; Tarascon, J.M. Building better batteries. Nature 2008, 451, 652-657. [CrossRef] [PubMed]

6. Xu, M.; Chen, Z.Y.; Li, L.J.; Zhu, H.L.; Zhao, Q.F.; Xu, L.; Peng, N.F.; Gong, L. Highly crystalline alumina surface coating from hydrolysis of aluminum isopropoxide on lithium-rich layered oxide. J. Power Sources 2015, 281, 444-454. [CrossRef]

7. Hu, B.; Lou, X.B.; Li, C.; Geng, F.S.; Zhao, C.; Wang, J.Y.; Shen, M.; Hu, B.W. Reversible phase transition enabled by binary Ba and Ti-based surface modification for high voltage $\mathrm{LiCoO}_{2}$ cathode. J. Power Sources 2019, 438, 226954-226961. [CrossRef]

8. Choi, J.W.; Aurbach, D. Promise and reality of post-lithium-ion batteries with high energy densities. Nat. Rev. Mater. 2016, 1, 1-16. [CrossRef]

9. Huang, W.; Wang, G.; Luo, C.; Xu, Y.B.; Xu, Y.; Ecksteina, B.J.; Chen, Y.; Wang, B.H.; Huang, J.X.; Kang, Y.J.; et al. Controllable growth of $\mathrm{LiMn}_{2} \mathrm{O}_{4}$ by carbohydrate-assisted combustion synthesis for high performance Li-ion batteries. Nano Energy 2019, 64, 103936-103945. [CrossRef]

10. Wang, Y.H.; Wang, Y.H.; Jia, D.S.; Peng, Z.; Xia, Y.Y.; Zheng, G.F. All-nanowire based Li-ion full cells using homologous $\mathrm{Mn}_{2} \mathrm{O}_{3}$ and $\mathrm{LiMn}_{2} \mathrm{O}_{4}$. Nano Lett. 2014, 14, 1080-1084. [CrossRef]

11. Gu, L.; Zhu, C.B.; Li, H.; Yu, Y.; Li, C.L.; Tsukimoto, S.; Maier, J.; Ikuhara, Y. Direct observation of lithium staging in partially delithiated $\mathrm{LiFePO}_{4}$ at atomic resolution. J. Am. Chem. Soc. 2011, 133, 4661-4663. [CrossRef] [PubMed]

12. Zhao, Y.; Peng, L.L.; Liu, B.R.; Yu, G.H. Single-crystalline $\mathrm{LiFePO}_{4}$ nanosheets for high-rate Li-ion batteries. Nano Lett. 2014, 14, 2849-2853. [CrossRef] [PubMed]

13. Myung, S.T.; Maglia, F.; Park, K.J.; Yoon, C.S.; Lamp, P.; Kim, S.J.; Sun, Y.K. Nickel-Rich Layered Cathode Materials for Automotive Lithium-Ion Batteries: Achievements and Perspectives. ACS Energy Lett. 2016, 2, 196-223. [CrossRef]

14. Yang, H.; Du, K.; Hu, G.R.; Peng, Z.D.; Cao, Y.B.; Wu, K.P.; Lu, Y.; Qi, X.Y.; Mu, K.C.; Wu, J.L. Graphene@TiO co-modified $\mathrm{LiNi}_{0.6} \mathrm{Co}_{0.2} \mathrm{Mn}_{0.2} \mathrm{O}_{2}$ cathode materials with enhanced electrochemical performance under harsh conditions. Electrochim. Acta 2018, 289, 149-157. [CrossRef]

15. Chen, Z.Y.; Gong, X.L.; Zhu, H.L.; Cao, K.F.; Liu, Q.M.; Liu, J.; Li, L.J.; Duan, J.F. High Performance and Structural Stability of $\mathrm{K}$ and $\mathrm{Cl}$ Co-Doped $\mathrm{LiNi}_{0.5} \mathrm{Co}_{0.2} \mathrm{Mn}_{0.3} \mathrm{O}_{2}$ Cathode Materials in 4.6 Voltage. Front. Chem. 2018, 6, 643-668. [CrossRef]

16. Chen, Z.Y.; Cao, K.F.; Zhu, H.L.; Li, L.J.; Gong, X.L.; Liu, Q.M.; Duan, J.F. Improved Electrochemical Performance of Surface Coated $\mathrm{LiNi}_{0.80} \mathrm{Co}_{0.15} \mathrm{Al}_{0.05} \mathrm{O}_{2}$ With Polypyrrole. Front. Chem. 2018, 6, 648-657. [CrossRef] [PubMed]

17. Yabuuchi, N.; Yoshii, K.; Myung, S.T.; Nakai, I.; Komaba, S. Detailed studies of a high-capacity electrode material for rechargeable batteries, $\mathrm{Li}_{2} \mathrm{MnO}_{3}-\mathrm{LiCo}_{1 / 3} \mathrm{Ni}_{1 / 3} \mathrm{Mn}_{1 / 3} \mathrm{O}_{2}$. J. Am. Chem. Soc. 2011, 133, 4404-4419. [CrossRef]

18. Ma, Y.T.; Liu, P.F.; Xie, Q.S.; Zhang, G.B.; Zheng, H.F.; Cai, Y.X.; Li, Z.; Wang, L.S.; Zhu, Z.Z.; Mai, L.Q.; et al. Double-shell Li-rich layered oxide hollow microspheres with sandwich-like carbon@spinel@layered@spinel@carbon shells as high-rate lithium ion battery cathode. Nano Energy 2019, 59, 184-196. [CrossRef]

19. Qing, R.P.; Shi, J.L.; Xiao, D.D.; Zhang, X.D.; Yin, Y.X.; Zhai, Y.B.; Gu, L.; Guo, Y.G. Enhancing the Kinetics of Li-Rich Cathode Materials through the Pinning Effects of Gradient Surface $\mathrm{Na}^{+}$Doping. Adv. Energy Mater. 2016, 6, 1501914-1501919. [CrossRef]

20. Ning, F.H.; Shang, H.F.; Li, B.; Jiang, N.; Zou, R.Q.; Xia, D.G. Surface thermodynamic stability of Li-rich $\mathrm{Li}_{2} \mathrm{MnO}_{3}$ : Effect of defective graphene. Energy Storage Mater. 2019, 22, 113-119. [CrossRef] 
21. Yan, P.F.; Nie, A.M.; Zheng, J.M.; Zhou, Y.G.; Lu, D.P.; Zhang, X.F.; Xu, R.; Belharouak, I.; Zu, X.T.; Xiao, J.; et al. Evolution of lattice structure and chemical composition of the surface reconstruction layer in $\mathrm{Li}_{1.2} \mathrm{Ni}_{0.2} \mathrm{Mn}_{0.6} \mathrm{O}_{2}$ cathode material for lithium ion batteries. Nano Lett. 2015, 15, 514-522. [CrossRef] [PubMed]

22. Liu, Y.Y.; Li, R.R.; Li, J.L.; Yang, Z.; Zhong, J.J.; Wang, Z.; Kang, F.Y. A high-performance Ce and Sn co-doped cathode material with enhanced cycle performance and suppressed voltage decay for lithium ion batteries. Ceram. Int. 2019, 45, 20780-20787. [CrossRef]

23. Shi, J.L.; Zhang, J.N.; He, M.; Zhang, X.D.; Yin, Y.X.; Li, H.; Guo, Y.G.; Gu, L.; Wan, L.J. Mitigating Voltage Decay of Li-Rich Cathode Material via Increasing Ni Content for Lithium-Ion Batteries. ACS Appl. Mater. Interfaces 2016, 8, 20138-20146. [CrossRef] [PubMed]

24. Xu, M.; Chen, Z.Y.; Zhu, H.L.; Yan, X.Y.; Li, L.J.; Zhao, Q.F. Mitigating capacity fade by constructing highly ordered mesoporous $\mathrm{Al}_{2} \mathrm{O}_{3}$ /polyacene double-shelled architecture in Li-rich cathode materials. J. Mater. Chem. A 2015, 3, 13933-13945. [CrossRef]

25. Ju, X.K.; Hou, X.; Liu, Z.Q.; Zheng, H.F.; Huang, H.; Qu, B.H.; Wang, T.H.; Li, Q.H.; Li, J. The full gradient design in Li-rich cathode for high performance lithium ion batteries with reduced voltage decay. J. Power Sources 2019, 437, 226902-226910. [CrossRef]

26. Gu, M.; Genc, A.; Belharouak, I.; Wang, D.P.; Amine, K.; Thevuthasan, S.; Baer, D.R.; Zhang, J.G.; Browning, N.D.; Liu, J.; et al. Nanoscale Phase Separation, Cation Ordering, and Surface Chemistry in Pristine $\mathrm{Li}_{1.2} \mathrm{Ni}_{0.2} \mathrm{Mn}_{0.6} \mathrm{O}_{2}$ for Li-Ion Batteries. Chem. Mater. 2013, 25, 2319-2326. [CrossRef]

27. Li, J.; Camardese, J.; Shunmugasundaram, R.; Glazier, S.; Lu, Z.G.; Dahn, J.R. Synthesis and Characterization of the Lithium-Rich Core-Shell Cathodes with Low Irreversible Capacity and Mitigated Voltage Fade. Chem. Mater. 2015, 27, 3366-3377. [CrossRef]

28. Sathiya, M.; Abakumov, A.M.; Foix, D.; Rousse, G.; Ramesha, K.; Saubanère, M.; Doublet, M.L.; Vezin, H.; Laisa, C.P.; Prakash, A.S.; et al. Origin of voltage decay in high-capacity layered oxide electrodes. Nat. Mater. 2014, 14, 230-238. [CrossRef]

29. Bettge, M.; Li, Y.; Gallagher, K.; Zhu, Y.; Wu, Q.L.; Lu, W.Q.; Bloom, I.; Abrahama, P.D. Voltage Fade of Layered Oxides Its Measurement and Impact on Energy Density. J. Electrochem. Soc. 2013, 160, A2046-A2055. [CrossRef]

30. Boulineau, A.; Simonin, L.; Colin, J.F.; Canévet, E.; Daniel, L.; Patoux, S. Evolutions of $\mathrm{Li}_{1.2} \mathrm{Mn}_{0.61} \mathrm{Ni}_{0.18} \mathrm{Mg}_{0.01} \mathrm{O}_{2}$ during the Initial Charge/Discharge Cycle Studied by Advanced Electron Microscopy. Chem. Mater. 2012, 24, 3558-3566. [CrossRef]

31. Wu, F.; Li, N.; Su, Y.F.; Zhang, L.J.; Bao, L.Y.; Wang, J.; Chen, L.; Zheng, Y.; Dai, L.Q.; Peng, J.Y.; et al. Ultrathin spinel membrane-encapsulated layered lithium-rich cathode material for advanced Li-ion batteries. Nano Lett. 2014, 14, 3550-3555. [CrossRef] [PubMed]

32. Bloom, I.; Trahey, L.; Abouimrane, A.; Belharouak, I.; Zhang, X.F.; Wu, Q.L.; Lu, W.Q.; Abraham, D.P.; Bettge, M.; Elam, J.W.; et al. Effect of interface modifications on voltage fade in $0.5 \mathrm{Li}_{2} \mathrm{MnO}_{3} \cdot 0.5 \mathrm{LiNi}_{0.375} \mathrm{Mn}_{0.375} \mathrm{Co}_{0.25} \mathrm{O}_{2}$ cathode materials. J. Power Sources 2014, 249, 509-514. [CrossRef]

33. Zheng, F.; Yang, C.; Xiong, X.; Xiong, J.; Hu, R.; Chen, Y.; Liu, M. Nanoscale Surface Modification of Lithium-Rich Layered-Oxide Composite Cathodes for Suppressing Voltage Fade. Angew. Chem. Int. Ed. Engl. 2015, 54, 13058-13062. [CrossRef]

34. Tian, Z.X.; Wang, J.L.; Liu, S.Z.; Li, Q.; Zeng, G.F.; Yang, Y.; Cui, Y.H. Na-stabilized Ru-based lithium rich layered oxides with enhanced electrochemical performance for lithium ion batteries. Electrochim. Acta 2017, 253, 31-38. [CrossRef]

35. Vu, A.; Walker, L.K.; Bareno, J.; Burrell, A.K.; Bloom, I. Effects of cycling temperatures on the voltage fade phenomenon in $0.5 \mathrm{Li}_{2} \mathrm{MnO}_{3} \cdot 0.5 \mathrm{LiNi}_{0.375} \mathrm{Mn}_{0.375} \mathrm{CO}_{0.25} \mathrm{O}_{2}$ cathodes. J. Power Sources 2015, 280, 155-158. [CrossRef]

36. Li, H.Y.; Cormier, M.; Zhang, N.; Inglis, J.; Li, J.; Dahn, J.R. Is Cobalt Needed in Ni-Rich Positive Electrode Materials for Lithium Ion Batteries? J. Electrochem. Soc. 2019, 166, A429-A439. [CrossRef]

37. Kim, U.H.; Kim, J.H.; Hwang, J.Y.; Ryu, H.H.; Yoon, C.S.; Sun, Y.K. Compositionally and structurally redesigned high-energy Ni-rich layered cathode for next-generation lithium batteries. Mater. Today 2019, 23, 26-36. [CrossRef]

38. Wang, J.; He, X.; Paillard, E.; Laszczynski, N.; Li, J.; Passerini, S. Lithium- and Manganese-Rich Oxide Cathode Materials for High-Energy Lithium Ion Batteries. Adv. Energy Mater. 2016, 6, 1600906-1600922. [CrossRef] 
39. Vu, A.; Qin, Y.; Lin, C.K.; Abouimrane, A.; Burrell, A.K.; Bloom, S.; Bass, D.; Bareno, J.; Bloom, I. Effect of composition on the voltage fade phenomenon in lithium-, manganese-rich $x \mathrm{LiMnO}_{3} \cdot(1-\mathrm{x}) \mathrm{LiNi}_{\mathrm{a}} \mathrm{Mn}_{\mathrm{b}} \mathrm{Co}_{\mathrm{c}} \mathrm{O}_{2}$ : A combinatorial synthesis approach. J. Power Sources 2015, 294, 711-718. [CrossRef]

40. Shi, J.L.; Xiao, D.D.; Ge, M.; Yu, X.; Chu, Y.; Huang, X.; Zhang, X.D.; Yin, Y.X.; Yang, X.Q.; Guo, Y.G.; et al. High-Capacity Cathode Material with High Voltage for Li-Ion Batteries. Adv. Mater. 2018, 30, 1705575-1705582. [CrossRef]

41. Hy, S.; Cheng, J.H.; Liu, J.Y.; Pan, C.J.; Rick, J.; Lee, J.F.; Chen, J.M.; Hwang, B.J. Understanding the Role of Ni in Stabilizing the Lithium-Rich High-Capacity Cathode Material $\mathrm{Li}\left[\mathrm{Ni}_{\mathrm{x}} \mathrm{Li}_{(1-2 \mathrm{x}) / 3} \mathrm{Mn}_{(2-\mathrm{x}) / 3}\right] \mathrm{O}_{2}(0 \leq \mathrm{x} \leq 0.5)$. Chem. Mater. 2014, 26, 6919-6927. [CrossRef]

42. Kim, T.; Song, B.H.; Lunt, A.G.; Cibin, G.; Dent, A.J.; Lu, L.; Korsunsky, A.M. In operando X-ray absorption spectroscopy study of charge rate effects on the atomic environment in graphene-coated Li-rich mixed oxide cathode. Mater. Des. 2016, 98, 231-242. [CrossRef]

43. Yang, F.; Zhang, Q.G.; Hu, X.H.; Peng, T.Y.; Liu, J.Q. Preparation of Li-rich layered-layered type $x \mathrm{Li}_{2} \mathrm{MnO}_{3} \cdot(1-\mathrm{x})$ $\mathrm{LiMnO}_{2}$ nanorods and its electrochemical performance as cathode material for Li-ion battery. J. Power Sources 2017, 353, 323-332. [CrossRef]

44. Yan, P.F.; Xiao, L.; Zheng, J.M.; Zhou, Y.G.; He, Y.; Zu, X.T.; Mao, S.X.; Xiao, J.; Gao, F.; Zhang, J.G.; et al. Probing the Degradation Mechanism of $\mathrm{Li}_{2} \mathrm{MnO}_{3}$ Cathode for Li-Ion Batteries. Chem. Mater. 2015, 27, 975-982. [CrossRef]

45. Wang, P.B.; Luo, M.Z.; Zheng, J.C.; He, Z.J.; Tong, H.; Yu, W.J. Comparative Investigation of $0.5 \mathrm{Li}_{2} \mathrm{MnO}_{3} .0 .5 \mathrm{LiNi}_{0.5} \mathrm{Co}_{0.2} \mathrm{Mn}_{0.3} \mathrm{O}_{2}$ Cathode Materials Synthesized by Using Different Lithium Sources. Front. Chem. 2018, 6, 159-167. [CrossRef]

46. Zhang, L.J.; Wu, B.R.; Li, N.; Wu, F. Hierarchically porous micro-rod lithium-rich cathode material $\mathrm{Li}_{1.2} \mathrm{Ni}_{0.13} \mathrm{Mn}_{0.54} \mathrm{Co}_{0.13} \mathrm{O}_{2}$ for high performance lithium-ion batteries. Electrochim. Acta 2014, 118, 67-74. [CrossRef]

47. Zhou, L.Z.; Xu, Q.J.; Liu, M.S.; Jin, X. Novel solid-state preparation and electrochemical properties of $\mathrm{Li}_{1.13}\left[\mathrm{Ni}_{0.2} \mathrm{Co}_{0.2} \mathrm{Mn}_{0.47}\right] \mathrm{O}_{2}$ material with a high capacity by acetate precursor for Li-ion batteries. Solid State Ion. 2013, 249-250, 134-138. [CrossRef]

48. Kandhasamy, S.; Pandey, A.; Minakshi, M. Polyvinylpyrrolidone assisted sol-gel route $\mathrm{LiCo}_{1 / 3} \mathrm{Mn}_{1 / 3} \mathrm{Ni}_{1 / 3} \mathrm{PO}_{4}$ composite cathode for aqueous rechargeable battery. Electrochim. Acta 2012, 60, 170-176. [CrossRef]

49. Navaratnarajah, K.; Efstratia, S.; Yerassimos, P.; Alexander, C. Defect Process, Dopant Behaviour and Li Ion Mobility in the $\mathrm{Li}_{2} \mathrm{MnO}_{3}$ Cathode Material. Energies 2019, 12, 1329.

50. Yang, S.Q.; Wang, P.B.; Wei, H.X.; Tang, L.B.; Zhang, X.H.; He, Z.J.; Li, Y.J.; Tong, H.; Zheng, J.C. $\mathrm{Li}_{4} \mathrm{~V}_{2} \mathrm{Mn}\left(\mathrm{PO}_{4}\right)_{4}$-stablized $\mathrm{Li}\left[\mathrm{Li}_{0.2} \mathrm{Mn}_{0.54} \mathrm{Ni}_{0.13} \mathrm{Co}_{0.13}\right] \mathrm{O}_{2}$ cathode materials for lithium ion batteries. Nano Energy 2019, 63, 103889-103898. [CrossRef]

51. Redel, K.; Kulka, A.; Plewa, A.; Molenda, J. High-Performance Li-Rich Layered Transition Metal Oxide Cathode Materials for Li-Ion Batteries. J. Electrochem. Soc. 2019, 166, A5333-A5342. [CrossRef]

52. Zuo, Y.X.; Li, B.; Jiang, N.; Chu, W.S.; Zhang, H.; Zou, R.Q.; Xia, D.G. A High-Capacity O2-Type Li-Rich Cathode Material with a Single-Layer $\mathrm{Li}_{2} \mathrm{MnO}_{3}$ Superstructure. Adv. Mater. 2018, 30, 1707255-1707259. [CrossRef] [PubMed]

53. Xiong, F.Y.; Tan, S.H.; Wei, Q.L.; Zhang, G.B.; Sheng, J.Z.; An, Q.Y.; Mai, L.Q. Three-dimensional graphene frameworks wrapped $\mathrm{Li}_{3} \mathrm{~V}_{2}\left(\mathrm{PO}_{4}\right)_{3}$ with reversible topotactic sodium-ion storage. Nano Energy 2017, 32, 347-352. [CrossRef]

54. Liu, J.L.; Chen, L.; Hou, M.Y.; Wang, F.; Che, R.C.; Xia, Y.Y. General synthesis of $x \operatorname{Li}_{2} \mathrm{MnO}_{3} \cdot(1-\mathrm{x})$ $\mathrm{LiMn}_{1 / 3} \mathrm{Ni}_{1 / 3} \mathrm{Co}_{1 / 3} \mathrm{O}_{2}$ nanomaterials by a molten-salt method: Towards a high capacity and high power cathode for rechargeable lithium batteries. J. Mater. Chem. 2012, 22, 25380-25387. [CrossRef]

55. Yang, X.K.; Wang, D.; Yu, R.Z.; Bai, Y.S.; Shu, H.B.; Ge, L.; Guo, H.P.; Wei, Q.L.; Liu, L.; Wang, X.Y. Suppressed capacity/voltage fading of high-capacity lithium-rich layered materials via the design of heterogeneous distribution in the composition. J. Mater. Chem. A 2014, 2, 3899-3911. [CrossRef]

(C) 2019 by the authors. Licensee MDPI, Basel, Switzerland. This article is an open access article distributed under the terms and conditions of the Creative Commons Attribution (CC BY) license (http://creativecommons.org/licenses/by/4.0/). 